Primljen / Received: 16.5.2013.

Ispravljen / Corrected: 14.10.2013.

Prihvaćen / Accepted: 15.11.2013.

Dostupno online / Available online: 10.12.2013.

\section{Ecological building design and evaluation in Ankara}

\section{Authors:}

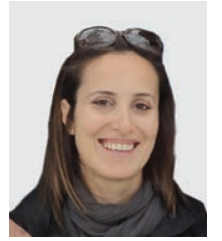

Assist.Prof. Arzuhan Burcu Gültekin, PhD. Arch.

University of Gazi

Faculty of Technology

Department of Civil Engineering

arzuhanburcu@yahoo.com

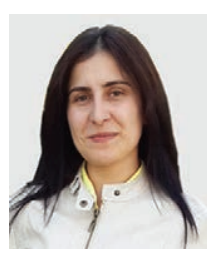

Bengü Alparslan Ersöz, BSc.

Beray Engineering

Ankara, Turkey

bengualparslan@gmail.com

\section{Arzuhan Burcu Gültekin, Bengü Alparslan Ersöz}

\section{Ecological building design and evaluation in Ankara}

The ecological building design is a response to environmental pollution caused by construction activity. Such design of buildings takes into account environmental problems and strives toward preserving ecological balance, while at the same time attempting to meet requirements for a healthy and comfortable living. Ecologically sustainable design measures are examined in the paper. A preliminary design of an ecological building named Gazi University Environmental Research and Training Laboratory (GUERTL) in Ankara, is analysed. According to the suggested evaluation method, the ecological performance of the building amounts to $88 \%$.

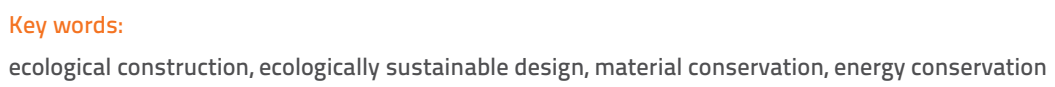

Stručni rad

Arzuhan Burcu Gültekin, Bengü Alparslan Ersöz

\section{Ekološki održivo projektiranje i ocjenjivanje zgrada u Ankari}

Ekološki održivo projektiranje zgrada odgovor je na zagadenja okoliša koja uzrokuje gradnja. Takvo projektiranje zgrada uzima u obzir probleme vezane za okoliš i teži očuvanju ekološke ravnoteže, a istodobno nastoji ispuniti uvjete za zdrav i udoban život. $\mathrm{U}$ radu su ispitane mjere ekološki održivog projektiranja. Analiziran je idejni projekt ekološke zgrade Laboratorij za ekološka istraživanja i obuku Sveučilišta u Gazi (GUERTL) u Ankari. Ekološka svojstva zgrade su prema predloženoj metodi ocjene i uspješnost takvog projektiranja procijenjena na $88 \%$.

Ključne riječi:

ekološka gradnja, ekološki održivo projektiranje, očuvanje materijala, očuvanje energije

Fachbericht

Arzuhan Burcu Gültekin, Bengü Alparslan Ersöz

\section{Ökologisch nachhaltiger Entwurf von Gebäuden in Ankara}

Der ökologisch nachhaltige Entwurf von Gebäuden hat sich als Antwort auf die verbreitete Umweltverschmutzung durch verschiedene Bauvorhaben entwickelt, um Probleme bezüglich der Umwelt zu berücksichtigen, die Erhaltung des ökologischen Gleichgewichts zu ermöglichen, und gleichzeitig die Anforderungen eines gesunden und behaglichen Lebensraumes zu erfüllen. In der vorliegenden Arbeit ist der Entwurf des ökologischen Gebäudes des Umweltforschungs- und Ausbildungslabors der Gazi Universität in Ankara (GUERTL) betrachtet. Die ökologischen Eigenschaften des Bauwerks sind nach der vorgeschlagenen Methode für die entsprechende Einschätzung mit einer Erfolgsrate von $88 \%$ beurteilt. 


\section{Introduction}

The contamination stemming from population growth, urbanization, and industrial development, is one of the most important problems of humanity, since it constitutes a threat against natural resources [1]. On a worldwide scale, $17 \%$ of clean water sources, $25 \%$ of forest products, and $40 \%$ of energy resources, are consumed by the building sector, and so the notion of ecological design has been developed for buildings $[2,3]$. The goal of ecological building design is to reduce the use of natural resources without disrupting the ecological balance, to use local resources economically, to minimize harmful effects of buildings on the environment, and to provide appropriate conditions for human comfort and health [4].

In the building sector of Turkey, the ecological building design has gained ground since 1980 and small-size ecological buildings with different functions have been designed by universities, research centres, and public institutions, for research and development purposes [5]. Of the current resources in Turkey, $28 \%$ is met by the country's own resources, while $72 \%$ is imported, and this rate is gradually increasing [6]. In parallel with this increase, some large-size ecological buildings, certificated with international green rating systems, have also been designed and constructed in recent years by private organizations. Nevertheless, severe problems have been encountered while adapting these international systems to local conditions, which is why they are not currently widely used in Turkey. As a solution to this problem, Turkish Green Building Council developed in December 2012 a beta version of the Turkish ecological building certification system for homes, compliant with local conditions and measures, which is currently at the testing stage $[7,8]$. This local system consists of eight main categories of ecological measures: integrated green project management, land use, water use, energy use, health and wellbeing, material and resource use, home living, and operation and maintenance. However, it seems that there are some gaps in the strategies and methods used with respect to different types of buildings. Some scientific methods or frameworks can therefore be created in order to guide relevant operators in the building sector to fill in these gaps.

Apart from the rating systems, significant improvements have been made in Turkey since 2000 with regard to environmental issues and energy efficiency. Although the mentioned issues have initially attracted the private sector only, they are now being considered by the government as well. Thus, various standards, laws, and regulations have been enacted in order to decrease energy consumption and promote heat insulation, especially for the existing buildings.

In the year 2000, the Turkish standard TS825 (Thermal Insulation Requirements for Buildings) has been put to mandatory use in the country. Its purpose is to conserve energy by limiting amounts of energy used for heating buildings, determine the standard calculation method that will be used in energy requirement calculations, and enable construction of energy efficient and highly comfortable buildings [9]. The Energy Efficiency Law was enacted in 2007 in order to increase efficiency in the use of energy resources and energy, so as to ensure effective use of energy, avoid generation of waste, ease the burden of energy costs on

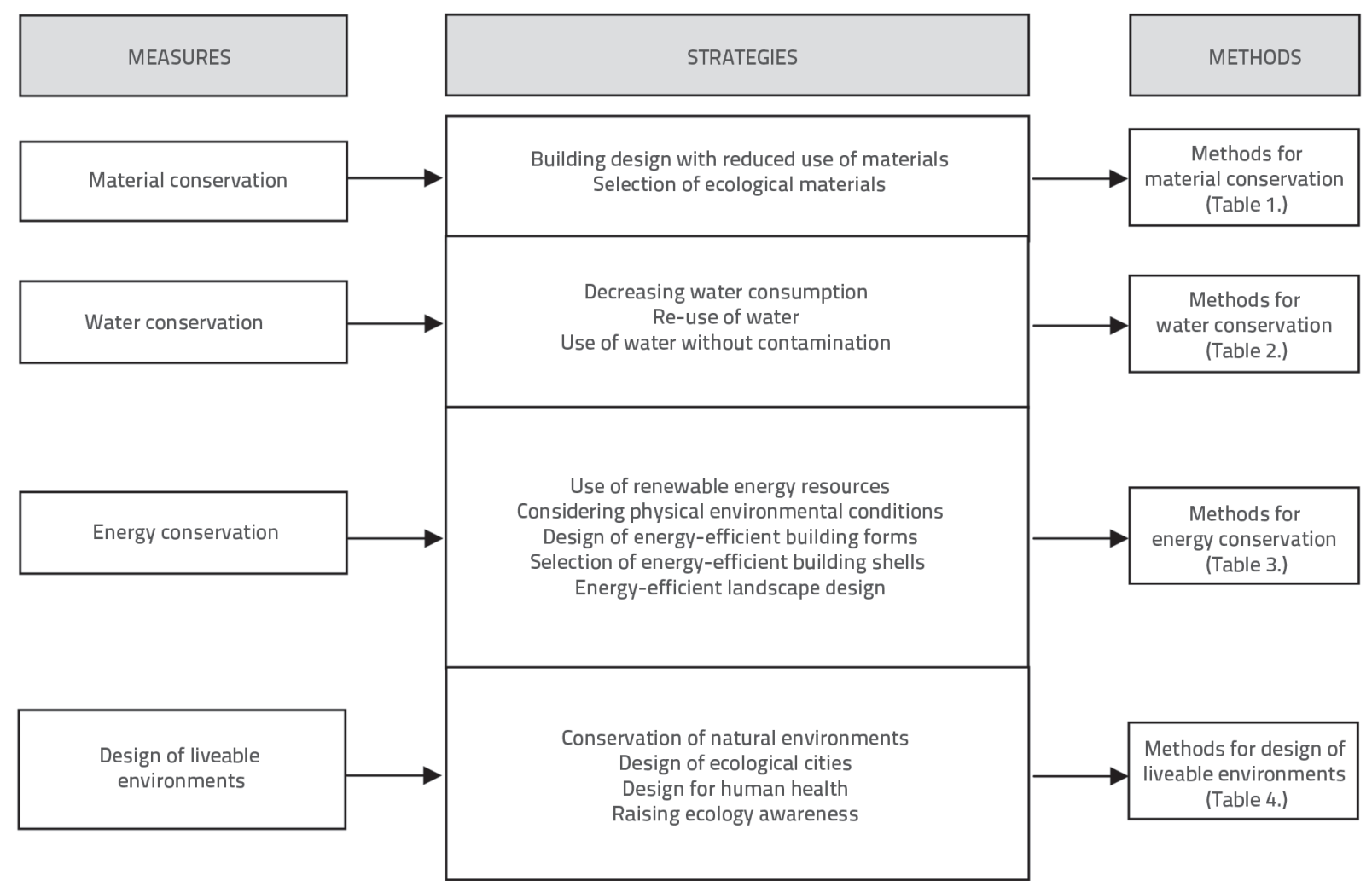

Figure 1. Proposed framework for ecological building design 
the economy, and protect environment [10]. Based upon this law, the Regulation on Energy Performance of Buildings [11] was put into force in 2011. According to this regulation, the Energy Identity Certificate is compulsory for new buildings since 2011, while it will become compulsory for the existing buildings by the year 2017. With regard to compulsory nature of this measure, local rating systems, including ecological building design measures, will unavoidably be implemented in Turkey in the foreseeable future. In this context, the intention of this paper is to increase awareness in the building sector of Turkey about the ecological building design measures, and to offer guidance to designers in terms of material conservation, water conservation, energy conservation, and design of liveable environments. In the scope of this intention, the aim of this paper is to propose a guiding framework for ecological building design to the designers operating in the building sector, in order to enable dissemination of ecological building design measures at the local level.

\section{Ecological building design}

The ecology is a discipline that deals with relations among and between organisms, and their environment [12]. It is also defined as the science of environment, and includes sub-fields such as the ecological building design [13]. The objective of the ecological building design is to decrease the water and energy consumption, maintenance-repair costs, defects related to buildings, waste and contamination, and also to increase the efficiency of building materials, building comfort, endurance of buildings and their components, and their flexibility $[14,15]$. Within the framework of these objectives, designers should adopt the principle of designing ecological buildings that minimize the consumption of materials, water and energy, and that use renewable and local resources, create healthy interior spaces, benefit from natural airconditioning and lighting, comply with physical environmental conditions, increase the energy conservation level within the building shell [16], and contain reusable, recycled and recyclable materials with lower maintenance-repair requirements $[17,18]$. Ecological buildings strive towards protecting the nature at the highest possible level, and providing the most suitable environment for people within the building [19]. Accordingly, ecological building design measures are classified in this paper into: material conservation, water conservation, energy conservation and design of liveable environments, on the basis of three scientific studies prepared by Çelebi, G., Gültekin, A.B., and Alparslan, B. [5, 20,21]. Based on these studies, a conceptual framework is proposed, with the strategies and methods for ensuring compliance with the ecological building design measures. This framework is presented in Figure 1, and the methods are elaborated in tables 1 - 4.

\section{Material conservation}

Material conservation can be ensured in the building sector by designing buildings that contribute to the lower use of building materials, and by choosing ecological building materials [5, 20, 21]. Strategies and methods for meeting material conservation objectives are given in Table 1.

Table 1. Strategies and methods for material conservation $[5,20,21]$

\begin{tabular}{|c|c|c|}
\hline \multirow{9}{*}{ 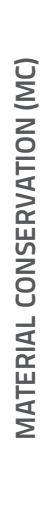 } & STRATEGIES & METHODS \\
\hline & \multirow{4}{*}{$\begin{array}{l}\text { Building design with reduced } \\
\text { use of materials (MC1) }\end{array}$} & Reducing the surface of building shell in the design (MC1.1) \\
\hline & & Use of simple geometric figures in the design (MC1.2) \\
\hline & & Designing buildings with efficient use of interior spaces (MC1.3) \\
\hline & & Reuse of existing buildings and infrastructure by renewal (MC1.4) \\
\hline & \multirow{4}{*}{$\begin{array}{l}\text { Selection of ecological } \\
\text { materials (MC2) }\end{array}$} & Selection of durable building systems and materials requiring less maintenance (MC2.1) \\
\hline & & $\begin{array}{l}\text { Selection of reusable, recycled and recyclable building materials that contain recycled materials in } \\
\text { packaging (MC2.2) }\end{array}$ \\
\hline & & Selection of natural building materials (MC2.3) \\
\hline & & Selection of local and regional building materials (MC2.4) \\
\hline
\end{tabular}

Table 2. Strategies and methods for water conservation [5, 20, 21]

\begin{tabular}{|c|c|c|}
\hline \multirow{9}{*}{ 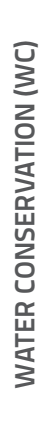 } & STRATEGIES & METHODS \\
\hline & \multirow{3}{*}{$\begin{array}{l}\text { Decreasing water } \\
\text { consumption (WC1) }\end{array}$} & Planning landscape that uses water efficiently and requires less maintenance (WC1.1) \\
\hline & & Using plants that are drought-tolerant and require less water (WC1.2) \\
\hline & & Using facilities with less water consumption (WC1.3) \\
\hline & \multirow{3}{*}{ Re-use of water (WC2) } & Reusing waste water by clarification (WC2.1) \\
\hline & & Using rainwater collecting facilities (WC2.2) \\
\hline & & Making arrangements that prevent water from mixing with ground water (WC2.3) \\
\hline & \multirow{2}{*}{$\begin{array}{l}\text { Use of water without } \\
\text { contamination (WC3) }\end{array}$} & Lower use of toxic pesticides (WC3.1) \\
\hline & & Using cleaning materials which do not cause contamination (WC3.2) \\
\hline
\end{tabular}


Table 3. Strategies and methods for energy conservation $[5,20,21]$

\begin{tabular}{|c|c|c|}
\hline \multirow{18}{*}{ 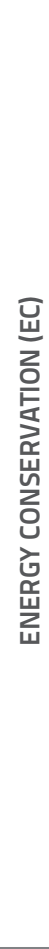 } & STRATEGIES & METHODS \\
\hline & \multirow{7}{*}{ Use of renewable energy resources (EC1) } & Using solar cells in electricity production (EC1.1) \\
\hline & & Using solar collectors for heating water (EC1.2) \\
\hline & & Using passive solar systems (EC1.3) \\
\hline & & Using wind energy in air-conditioning and cooling (EC1.4) \\
\hline & & Using daylight for lighting (EC1.5) \\
\hline & & Using geothermal energy for heating and cooling (EC1.6) \\
\hline & & Using energy-efficient systems and instruments (EC1.7) \\
\hline & \multirow{2}{*}{$\begin{array}{l}\text { Considering physical environmental conditions } \\
\text { (EC2) }\end{array}$} & Effective positioning of the building (EC2.1) \\
\hline & & Choosing suitable area for building location (EC2.2) \\
\hline & \multirow{3}{*}{ Design of energy-efficient building forms (EC3) } & Using simple geometric figures in the design (EC3.1) \\
\hline & & Designing structures with effective use of interior spaces (EC3.2) \\
\hline & & Increasing solar gain by widening south-oriented zones (EC3.3) \\
\hline & \multirow{2}{*}{ Selection of energy-efficient building shells (EC4) } & Preventing heat loss by choosing proper insulation materials (EC4.1) \\
\hline & & Using high-performance floor coverings and glass (EC4.2) \\
\hline & \multirow{3}{*}{ Energy-efficient landscape design (EC5) } & Using plants for heating and cooling (EC5.1) \\
\hline & & Using green roof applications (EC5.2) \\
\hline & & Using renewable landscape plans (EC5.3) \\
\hline
\end{tabular}

Table 4. Strategies and methods for design of liveable environments [5, 20, 21]

\begin{tabular}{|c|c|c|}
\hline \multirow{18}{*}{ 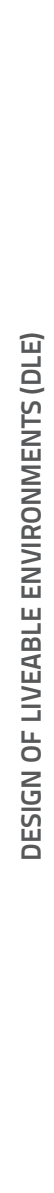 } & STRATEGIES & METHODS \\
\hline & \multirow{7}{*}{ Conservation of natural environments (DLE1) } & $\begin{array}{l}\text { Conservation of current plant cover and aquatic and terrestrial living creatures } \\
\text { (DLE1.1) }\end{array}$ \\
\hline & & Conservation of the topographic structure (DLE1.2) \\
\hline & & Conservation of underground and aboveground water levels (DLE1.3) \\
\hline & & Conservation of natural resources and natural living spaces (DLE1.4) \\
\hline & & Restoration of damaged ecosystems (DLE1.5) \\
\hline & & Repair and reuse of the current structure and infrastructure (DLE1.6) \\
\hline & & $\begin{array}{l}\text { Building materials detrimental to natural balance should be avoided at the produc- } \\
\text { tion phase (DLE1.7) }\end{array}$ \\
\hline & \multirow{3}{*}{ Design of ecological cities (DLE2) } & Prevention of pollution (visual, noise, air, soil) (DLE2.1) \\
\hline & & Development multi-functional designs (DLE2.2) \\
\hline & & $\begin{array}{l}\text { Decreasing use of automobiles by building roads for pedestrians and bicycles only } \\
\text { in the area around the building (DLE2.3) }\end{array}$ \\
\hline & \multirow{4}{*}{ Design for human health (DLE3) } & Using water-based natural materials in interior spaces (DLE3.1) \\
\hline & & Using naturally-dried preservative-free wood in interior spaces (DLE3.2) \\
\hline & & $\begin{array}{l}\text { Using adequate amount of sub-basement and water tables on the walls to prevent } \\
\text { dampness (DLE3.3) }\end{array}$ \\
\hline & & Providing for adequate movement and quality of air in interior spaces (DLE3.4) \\
\hline & \multirow{3}{*}{ Raising ecology awareness (DLE4) } & $\begin{array}{l}\text { Developing methods to help the society gain ecological experience in buildings } \\
\text { (DLE4.1) }\end{array}$ \\
\hline & & $\begin{array}{l}\text { Implementing research and development studies and developing curricula in edu- } \\
\text { cational institutions (DLE4.2) }\end{array}$ \\
\hline & & Organizing ecology and environment seminars for all segments of society (DLE4.3) \\
\hline
\end{tabular}




\section{Water conservation}

The use of water begins at the construction phase of the building and continues throughout the use of the building [22]. In the building sector, water economies can be made by decreasing water consumption, reusing water, and using water without contamination $[5,20,21]$. The strategies and methods for meeting water conservation objectives are given in Table 2 .

\section{Energy conservation}

Energy consumption begins at the production phase and continues during the phase of construction and use of the building. In the building sector, energy conservation can be ensured by using renewable energy resources, by considering physical conditions of the area under study, by designing energy-efficient building forms, by choosing energy-efficient building shells and, finally, by designing energy-efficient landscape [5, 20,21]. The strategies and methods for meeting energy conservation objectives are given in Table 3.

\section{Design of liveable environments}

The basic objective of the building sector is to create artificial environments with due regard for the safety, health, physiological needs, and productivity of the users. In these environments, human beings and other living and non-living organisms have to share common spaces [23]. In the building sector, the design of liveable environments can be ensured by conserving natural environments, designing ecological cities, taking into consideration human health, and raising awareness about ecology [5, 20, 21, 24]. The strategies and methods for meeting the design of liveable environment objectives are given in Table 4.

\section{Design and evaluation of an ecological building in Ankara}

This paper presents an example of an ecological building designed as a concept project in Ankara, the capital city of Turkey, which is located in the Central Anatolia Region [5, 21]. Furthermore, the designed building is evaluated within the framework of the ecological building design presented in Figure 1. According to the Ankara Province Environmental Status Report prepared by the Ankara Governorship Environment and Forest Directorate, Ankara is currently faced with several environmental problems [25]. These problems are related the to the air, water, soil and noise pollution due to dense, low-quality, non-standard and unhealthy settlements that were constructed in parallel with the rapid development of industrialization and population growth. Thus, designers should adopt ecological building design measures which will decrease environmental problems due to the condition of buildings in the city, and these measures should be implemented in accordance with physical conditions prevailing in the city. Ankara has a mild-dry climate; summers are warm and dry, while winters are cold and rainy. There is almost no rainfall in summer, and relative humidity is low. Fogs are frequent in wintertime. The number of days with frost ranges from 60 to 114, and the number of snowy days varies from 17 to 42, according to an annual average. The warmest months are July and August, while the coldest month is January. According to an annual average, Ankara benefits from sunlight for 7.4 hours a day. Strong winds usually occur in March and April. The dominant wind direction in Yenimahalle is northeast, with an average of $3,2 \mathrm{~m} / \mathrm{sec}$ [25].

Taking these features into consideration, the ecological building design for a mild-dry climate region should benefit from wind with a compact building form which has a large surface, rectangular or free plan; exterior walls with comforting insulation for interior spaces; slopped roofs with effective insulation; and window spaces large enough for heat control [26].

\subsection{Implementation of the design}

The Gazi University Central Campus is located in Yenimahalle county of Ankara. In the satellite image given in Figure 2, the area indicated with red lines is an idle, dysfunctional, neglected area, which doesn't contain any green space. It is situated behind the workshops of the Gazi University Faculty of Technology, Department of Civil Engineering, in the Gazi University Central Campus. This area has been selected for the implementation of the ecological building design, and relevant design decisions have been taken on the basis of physical environmental conditions of this area.

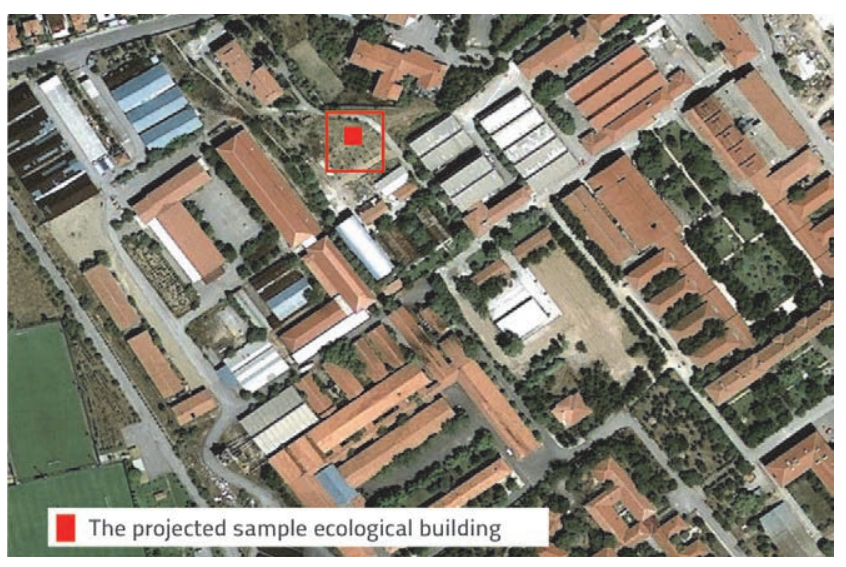

Figure 2. Satellite image of Gazi University Central Campus [27]

Gazi University does not have a sample building suitable for the on-site implementation of qualitative and quantitative measurements and evaluations regarding ecological performance of buildings, and for providing data on the use of simulation programs. Thus, a sample ecological building has been designed as a concept project by the authors of this paper, who are architect and technical draftsman by profession. The building was named Gazi University Environmental Research and Training Laboratory (GUERTL). Engineers specializing in ecological design should also be involved on the project for the construction phase of GUERTL.

The principal objective of GUERTL is to enable measurement and evaluation of the ecological performance of buildings and assessment of the compliance of buildings with the environment by means of research and development studies on environmental issues, related courses on the undergraduate and graduate levels, ecological material promotions, training seminars, courses, conferences, and panels. 

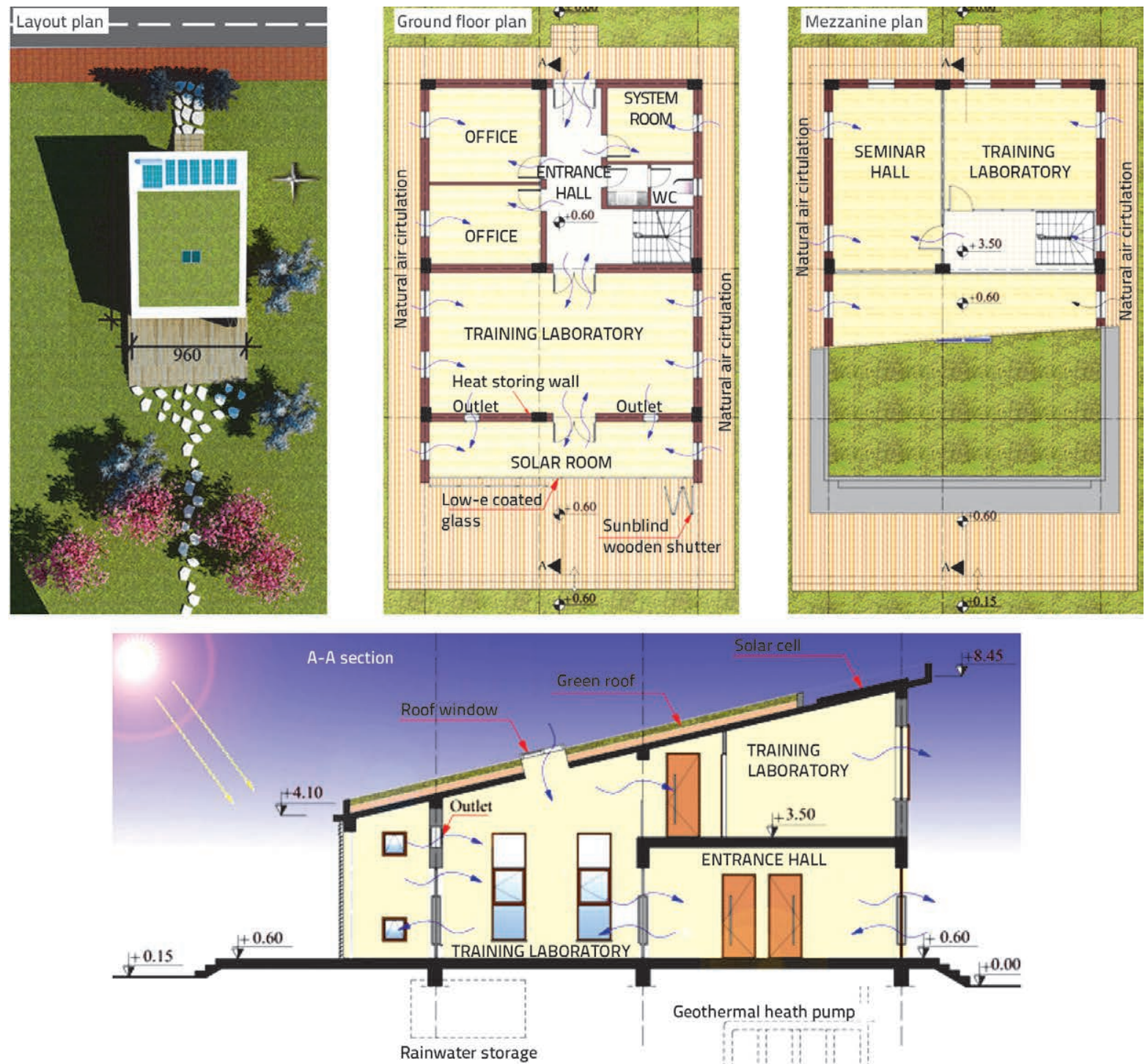

South-east perspective
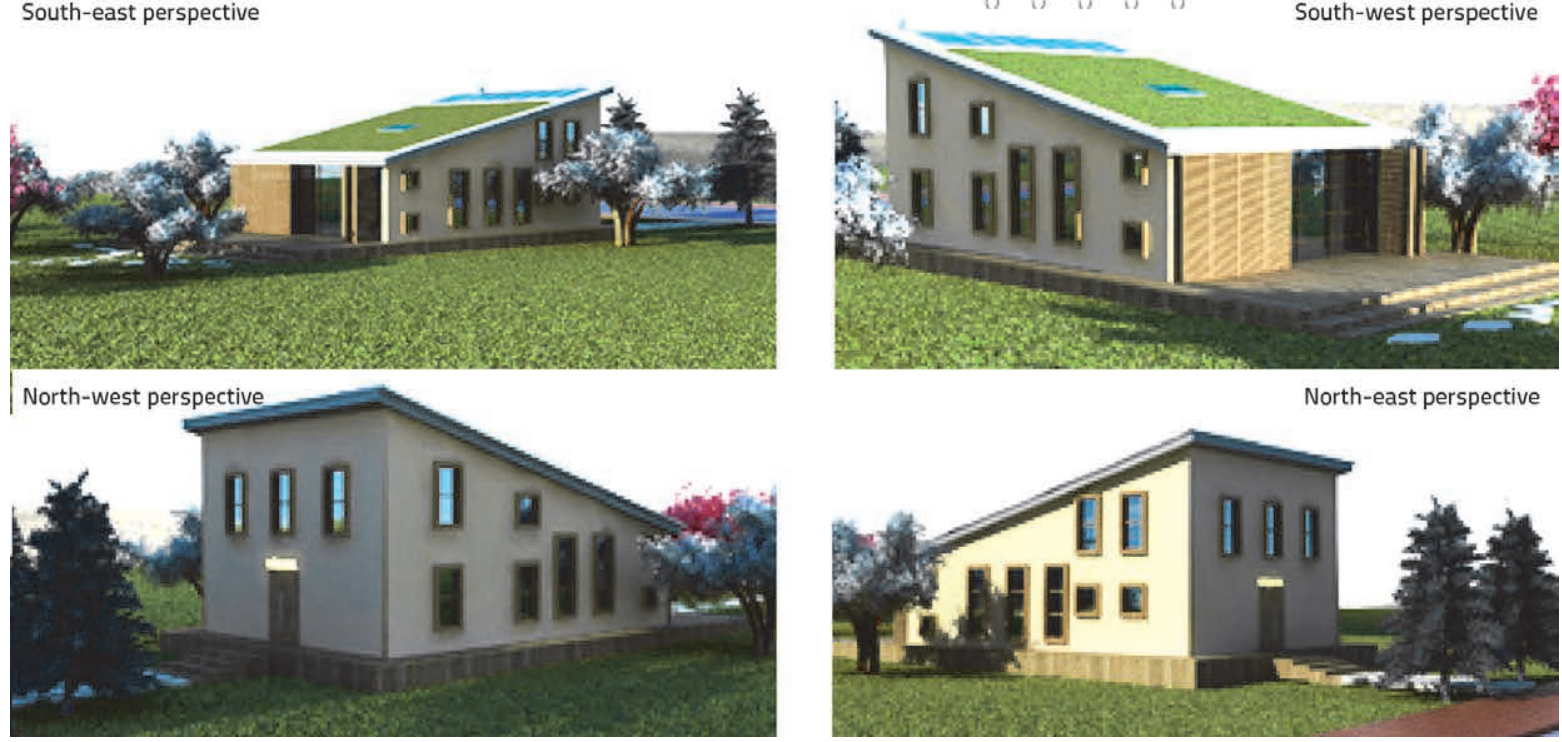

Figure 3. Concept design of Gazi University Environmental Research and Training Laboratory - GUERTL 
In the scope of this objective, GUERTL has been designed as a two-floor structure occupying $192 \mathrm{~m}^{2}$ in total area, with the $132 \mathrm{~m}^{2}$ ground floor, and the $60 \mathrm{~m}^{2}$ clerestory. The ground floor consists of a training laboratory where ecological building materials can be exhibited and promoted, two offices that can be used as work rooms when necessary, a system room, and a toilet. The clerestory level contains a research laboratory where research projects and simulation programs on the ecological performance of buildings can be implemented, and a seminar hall where seminars and scientific meetings can be organised. The concept of the GUERTL project, with the layout plan, floor plans, cross section and perspectives, is presented in Figure 3.

GUERTL design decisions related to material conservation, water conservation, energy conservation, and design of liveable environments, which are based on the conceptual framework presented in Figure 1, are described below. In this perspective, GUERTL assumes the function of an ecological building design office where ecological building design measures, strategies and methods are implemented.

\section{Design Decisions Regarding Material Conservation (MC)}

MC1: GUERTL has been designed as a structure of rectangular form in order to reduce the building shell surface and decrease heat loss and gain. The building is to use current infrastructure of the Gazi University Central Campus.

MC2: GUERTL has been designed with the reinforced concrete construction system by using ecological building materials such as wood, ceramics, and gas concrete, which can be obtained from facilities located in Ankara and surrounding areas, with recycled packages. Gas concrete is preferred for walls as it conserves energy by providing heat insulation at the production phase, and as it is inflammable. As 80 percent of the gas concrete volume is empty, it ensures greater production with fewer raw materials, and the waste material produced at the production phase is entirely recyclable. At the same time, the amount of gas emissions at the production phase is lower, compared to other construction materials [28]. Boards for floor coverings are made of natural timber coloured with non-toxic paints. The walls are painted in whitewash. A naturally-produced ceramic is preferred in wet areas. However, artificial extruded polystyrene is used for insulation, while concrete is used in the load carrying system.

\section{Design Decisions Regarding Water Conservation (WC)}

WC1: An irrigation system with taps and flushers that use water effectively is preferred in wet areas of GUERTL. Plants such as wild roses, thyme, carnation, and chamomile, are used in landscaping, as they are drought-tolerant and do not need much care and water. However, the grass used around the building requires much water.

WC2: The decision was made to place a rainwater storage near GUERTL, and use the rainwater in flushers for irrigation. However, the effectiveness of this method may be low due to the fact that the precipitation rate in Ankara is low. In addition, the designers decided to use $10 \mathrm{~cm}$ green roof system to collect rainwater, provide insulation, create a habitat for wildlife, help in lowering urban air temperatures, and mitigate heat island effects [5]. The green roof will have layers of vegetation, growing media, root permeable filter layer, drainage and capillarity layer, protection and storage layer, waterproofing, and roof deck. The turfstone, which is a permeable material, is preferred in the walkways as it allows rainwater to seep into the ground instead of draining into the municipal storm-water sewer. Decorative plants that require excessive care and water are not used.

WC3: Local plants are used around GUERTL as they are suitable for the climate of Ankara and tolerant against harmful insects. The need for pesticides is eliminated.

\section{Design Decisions Regarding Energy Conservation (EC)}

EC1: Six solar cells are placed on the roof of GUERTL to enable electricity production, and two solar collectors are used for hot water. The hot water will be stored in insulated tanks and provide water at desired temperatures using the heat exchanger control unit located in the tanks. A solar room covered with low-e coated glass has been designed at the south front for passive cooling and heating. Gas concrete is used in the wall between the solar room and interior space, and the exterior surface is to be painted in black to increase heat gain. Small outlets are placed at the lower and upper parts of this wall. Thus the warm air can be transferred from the solar room to interior spaces through the upper outlets, and the cool air can be transferred from interior spaces to the solar room through lower outlets. A north-south oriented corridor is planned in the interior space so that the doors and windows opened in this corridor will permit natural air circulation. Natural air conditioning will be ensured by the outlets in the upper part of the solar room. These outlets will let the warm air out, while fresh and cool air will come through the windows. Light colours are used in interior spaces to lower the need for using artificial lightening, to prevent absorption, and to brighten up the interior space. A roof window is placed on the roof. Wooden shutters, which can be operated both horizontally and vertically, have been designed in order to prevent heat loss through windows, and to prevent penetration of sunlight when needed. The decision was also made to use geothermal heat pumps for heating in winter and cooling in summer, and to adopt automated lightning systems in order to increase energy-efficiency.

EC2: The dominant sunlight directions in Ankara vary between south and the $30^{\circ}$ east and $30^{\circ}$ west of south [29]. The decision was therefore made to direct rectangularly-shaped GUERTL towards south to increase solar gain. The idle, dysfunctional and neglected area without any green space, situated behind the workshops and laboratories of the Gazi University Faculty of Technology, Department of Civil Engineering, has been selected as a suitable location for GUERTL.

EC3: Rectangular building form has been adopted in the design of GUERTL. In addition, GUERTL is directed towards south in order to increase solar gain. But due to its rectangular form, the north front expanded at the same rate as the south front, which imposed the need to provide for an additional heat insulation. EC4: The decision was therefore made to use $30 \mathrm{~cm}$ thick gas concrete for exterior walls, and to insulate this concrete with 5 
$\mathrm{cm}$ thick extruded polystyrene foam, and $2 \mathrm{~cm}$ thick ecological insulation plaster. $20 \mathrm{~cm}$ thick gas concrete is to be used for interior walls, while $4 \mathrm{~cm}$ thick extruded polystyrene foam is used as insulation under the floor covering. In compliance with the Turkish standard TS 825, the glass with a low u-value of less than $0.80 \mathrm{~W}\left(\mathrm{~m}^{2} \mathrm{~K}\right)$, with low gain coefficient, and with high visibility is used [9]. Wood board floor covering from natural timber has been adopted. In addition, low-e coated glass is used in solar room, which provides for heat gain with its high permeability during the day, and heat insulation with low irradiation at the night-time. EC5: The landscaping planned for GUERTL contributes to the ecological function of the building. Trees suitable for the climate of Ankara, deciduous trees in the south of the building, and evergreen trees in the north [30], are planned. Thus, pine trees have been planted in the north, while juniper and oak trees have been planted in the south. In addition, apple, pear and cherry trees are located around the house. The decision was made to build a green roof because it helps collect rainwater, the area used by the building is restored to nature, and the natural habitat is improved. In this way, the plants and soil on the roof will help the cooling process by evaporating water in summer, moisturizing the air and cooling the building naturally. On the other hand, the soil layer will ensure natural insulation in the wintertime.

\section{Design decisions regarding design of liveable environments (DLE)} DLE1: No intervention has been made in the topographic structure of the building area. An idle field will thus be repaired and reclaimed, and the current infrastructure of the Gazi University will be used.

DLE2: GUERTL has been designed in form of an ecological building, which contributes to the reduction of environmental pollution through appropriate methods for energy conservation, water conservation, and material conservation. Moreover, no car park is designed around GUERTL to encourage public transportation and decrease the use of automobiles. However, the use of automobiles is already allowed within the campus.

DLE3: Whitewash is used on walls, and non-toxic paints are used on wooden surfaces of GUERTL. Ceramic material is used in wet areas and natural timber is preferred in other areas as floor covering. $60 \mathrm{~cm}$ sub-basement is applied on walls, and $50 \mathrm{~cm}$ water tables are used in order to prevent humidity.

DLE4: In the design of GUERTL, the opportunity is provided to experience harmonization of the building with the environment. Spaces are designed for environment-related experimental studies, research and development, and also for relevant undergraduate and graduate courses. Seminars and conferences are to be organized to promote the building and relationship with nature through appropriate design of living space.

\subsection{Ecological evaluation of the design}

An evaluation method is developed in this section in order to determine the ecological success level of GUERTL's design. This evaluation is based on an objective scoring by determining the evaluation measures, the implementation status of these measures in the design, and the implementation success. Three points are awarded for successful implementation of evaluation measures, two points for implementation with an average success, one point for unsuccessful implementation, and zero points if evaluation measures are not implemented. The evaluation legend is presented in Table 5.

Table 5. Evaluation legend

\begin{tabular}{|c|c|c|}
\hline Points & $\begin{array}{c}\text { Implementation } \\
\text { status }\end{array}$ & $\begin{array}{c}\text { Implementation } \\
\text { success }\end{array}$ \\
\hline 0 & Not implemented & - \\
\hline 1 & Implemented & Unsuccessful \\
\hline 2 & Implemented & Average success \\
\hline 3 & Implemented & Successful \\
\hline
\end{tabular}

Table 6. Table of ecological evaluation of GUERTL

\begin{tabular}{|c|c|c|c|c|c|}
\hline \multicolumn{2}{|c|}{ Evaluation measures } & \multirow{2}{*}{$\begin{array}{c}\text { Points } \\
3\end{array}$} & \multicolumn{2}{|c|}{ Evaluation measures } & Points \\
\hline \multirow{8}{*}{ 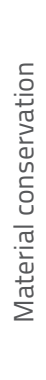 } & MC1.1 & & \multirow{8}{*}{ 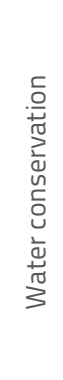 } & WC1.1 & 3 \\
\hline & MC1.2 & 3 & & WC1.2 & 2 \\
\hline & MC1.3 & 3 & & WC1.3 & 3 \\
\hline & MC1.4 & 3 & & WC2.1 & 0 \\
\hline & MC2.1 & 2 & & WC2.2 & 2 \\
\hline & MC2.2 & 2 & & WC2.3 & 3 \\
\hline & MC2.3 & 2 & & WC3.1 & 3 \\
\hline & MC2.4 & 3 & & WC3.2 & - \\
\hline \multicolumn{2}{|c|}{ Total points } & 21 & \multicolumn{2}{|c|}{ Total points } & 16 \\
\hline \multicolumn{2}{|c|}{ Section points } & 24 & \multicolumn{2}{|c|}{ Section points } & 21 \\
\hline \multicolumn{2}{|c|}{ Success [\%] } & 88 & \multicolumn{2}{|c|}{ Success [\%] } & 76 \\
\hline \multirow{17}{*}{ 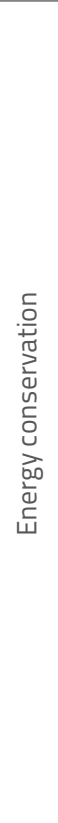 } & EC1.1 & 3 & \multirow{17}{*}{ 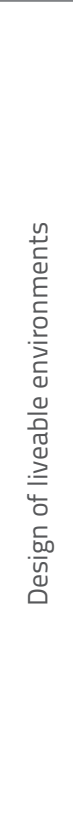 } & DLE1.1 & - \\
\hline & EC1.2 & 3 & & DLE1.2 & 3 \\
\hline & EC1.3 & 3 & & DLE1.3 & 3 \\
\hline & EC1.4 & 3 & & DLE1.4 & - \\
\hline & EC1.5 & 3 & & DLE1.5 & 3 \\
\hline & EC1.6 & 3 & & DLE1.6 & 3 \\
\hline & EC1.7 & 3 & & DLE1.7 & 2 \\
\hline & EC2.1 & 3 & & DLE2.1 & 2 \\
\hline & EC2.2 & 3 & & DLE2.2 & - \\
\hline & EC3.1 & 3 & & DLE2.3 & 0 \\
\hline & EC3.2 & 3 & & DLE3.1 & 3 \\
\hline & EC3.3 & 2 & & DLE3.2 & 3 \\
\hline & EC4.1 & 3 & & DLE3.3 & 3 \\
\hline & EC4.2 & 3 & & DLE3.4 & 3 \\
\hline & EC5.1 & 3 & & DLE4.1 & 3 \\
\hline & EC5.2 & 3 & & DLE4.2 & 3 \\
\hline & EC5.3 & 3 & & DLE4.3 & 3 \\
\hline \multicolumn{2}{|c|}{ Total points } & 50 & \multicolumn{2}{|c|}{ Total points } & 37 \\
\hline \multicolumn{2}{|c|}{ Section points } & 51 & \multicolumn{2}{|c|}{ Section points } & 42 \\
\hline \multicolumn{2}{|c|}{ Success [\%] } & 98 & \multicolumn{2}{|c|}{ Success [\%] } & 88 \\
\hline & & DTAL SU & ESS: & & \\
\hline
\end{tabular}


Evaluation measures have been accepted as the ecological building design measures, which are in turn classified as material conservation, water conservation, energy conservation, and design of liveable environments in Section 2. For evaluation purposes, each measure is discussed in multiple directions and graded on the basis of points given in the evaluation legend. Finally, the success of the design is calculated in terms of percentage, as shown in Table 6.

According to the ecological evaluation of GUERTL presented in Table 6, GUERTL is $88 \%$ successful in terms of material conservation, $76 \%$ successful in terms of water conservation, $98 \%$ successful in terms of energy conservation, and 88 $\%$ successful in terms of design of liveable environments. Consequently, it is $88 \%$ successful on the basis of total points. The ecological evaluation chart of GUERTL is given in Figure 4. In future studies, more comprehensive evaluation methods can be developed so as to provide useful data for simulation programs and green rating systems.

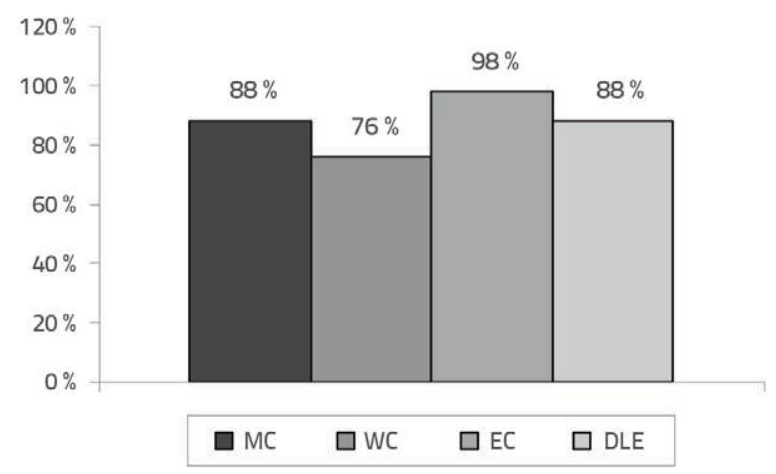

Figure 4. Ecological Evaluation of GUERTL

\section{Conclusions}

In this paper, ecological building design measures, and strategies and methods for implementing these measures, are analyzed within a conceptual framework. In this framework, a sample ecological building, to be used as an environmental research and educational laboratory, has been designed in Ankara - Turkey where intense environmental problems have emerged due to the dense and low-quality structuring [25]. The mentioned building GUERTL has been designed at the Gazi University, where qualitative and quantitative measurements and evaluations regarding the ecological performance of buildings can be carried out in practical terms. GUERTL is expected to offer guidance for the ecological building design process, and to become an information centre for future ecological building design to be carried out in Ankara, as well as a structure that will raise awareness on ecological building design measures. The most important feature of GUERTL is that it sets an example for other ecological building designs and evaluations by implementing the ecological building design measures to the greatest possible extent. The findings resulting from ecological evaluation of GUERTL, for each ecological building design measure, can be interpreted as follows:

- For energy conservation in GUERTL, the target is to use renewable energy resources, consider physical environmental conditions of the design area, design energy-efficient building forms, choose energy-efficient building shells, and design an energy-efficient landscape. In line with these objectives, EC1.1, EC1.2, EC4.1, EC4.2, EC5.1, EC5.2, EC5.3, EC1.3, EC1.4, EC1.5, EC1.6, EC1.7, EC2.1, EC2.2, EC3.1 and EC3.2 were implemented successfully. EC3.3 were implemented but with an average success because the rectangular form of GUERTL expands the north front at the same rate as the south front, which imposed the need to ensure an additional heat insulation.

- For water conservation in GUERTL, the target is to decrease water consumption, reuse water and use water without contamination. In line with these objectives, WC1.1, WC1.3, WC2.3 and WC3.1 were implemented successfully. WC1.2 were implemented but with an average success because the grass used around the building requires much water and, similarly, WC2.2 were implemented with an average success because the effectiveness of using rainwater collecting facilities may be low due to the fact that the rainfall in Ankara is low. On the contrary, WC2.1 was not implemented as it is considered that the quantity of waste water would not be significant in such a small-size building, and WC3.2 was ignored as this measure is related to the stage when the building will actually be used.

- For material conservation in GUERTL, the target is to decrease the use of building materials and choose ecological building materials. In line with these objectives, MC1.1, MC1.2, MC1.3, MC1.4 and MC2.4 were implemented successfully. MC2.1 were implemented but with an average success because the reinforced concrete is used as the carrier system and, similarly, MC2.2 and MC2.3 were implemented with an average success because an artificial extruded polystyrene is used for insulation due to its highperformance.

- For the design of liveable environments in GUERTL, the target is to conserve natural environments, design ecological cities, consider human health, and raise awareness about ecological issues. In line with these objectives, DLE1.2, DLE1.3, DLE1.5, DLE1.6, DLE3.1, DLE3.2, DLE3.3, DLE3.4, DLE4.1, DLE4.2 and DLE4.3 were implemented successfully. DLE1.7 were implemented but with an average success because the reinforced concrete is used as the carrier system, and an artificial extruded polystyrene is used for insulation and, similarly, DLE2.1 were implemented with an average success because it is assumed that maximum measures have not been taken to prevent pollution. On the other hand, DLE2.3 was not implemented because it is allowed to use automobiles within the campus. DLE1.1 and DLE1.4 were ignored as 
there are no aquatic and terrestrial living creatures, natural resources and natural living spaces in the zone under study. Similarly, DLE2.2 was ignored as this measure is significant for settlement units at the urban level.

In line with the above mentioned findings, the ecological evaluation of GUERTL has revealed that the material conservation amounts to $88 \%$, water conservation to $76 \%$, energy conservation to $98 \%$, and design of liveable environments to $88 \%$. According to evaluation results based on the total number of points, the success rate of ecological building design measures taken at GUERTL amounts to $88 \%$. These high rates are significant and so that the design framework of GUERTL can be used as a role model for other ecological building designs to be implemented in Turkey. In this sense, this guiding framework may contribute to the creation of a databank for ecological building designs and ratings in Ankara, by providing data for local databanks of the Ministry of Energy and Natural Resources, and the Ministry of Environment and Urban Planning of Turkey. This project may also encourage development of ecological assessment based simulation programs, energy calculation methods, and green rating systems to be implemented in Turkey. Moreover, the data obtained from such a small-size building design can be utilised as a guide for larger-size building designs both at the local and global levels.

Although various small and large size ecological building designs have been implemented in Turkey, it can generally be stated that the number of these projects is not sufficient, and that the quality achieved necessitates further improvement. This is due to the fact that we are currently faced with the lack of an ecological point of view in architectural design approaches currently used by designers in Turkey. Thus, it is crucial for the designers to integrate in their architectural design approaches the relations that have been presented from an ecological point of view as a guiding framework in this paper. Thereby, designers should contribute to the rise of ecological awareness both in the building sector and the society as a whole. In addition, educational institutions should provide courses and seminars with the same purpose. On the other hand, this ecological point of view should be supported by scientific research, education programs, standards, and by appropriate laws and regulations.

In Turkey, ecological building design measures are not adequately covered by regulations and standards on ecological concerns and energy efficiency. Consequently, it is of vital significance to develop new legal instruments and study new standards that would focus of the totality of ecological building design measures. In this context, the ecological building design framework proposed in this paper should serve as a guideline for further development of legal regulations, scientific research incentives, educational programs, and architectural design guidelines in Turkey.

\section{Acknowledgement}

This paper is supported by the Gazi University in the scope of the scientific research project (No. 07/2009-34) entitled "Analysis and Evaluation of Ecological Building Design Criteria within the Context of a Building Example". The authors appreciate the assistance provided in this respect.

\section{REFERENCES}

[1] Sakellariadou, F.: Industrial Activity and its Effects on Air and Water Quality, Journal of Environmental Protection and Ecology, 6 (2000) 3 pp. 247-254.

[2] Say, C. \& Wood, A.: Sustainable Rating Systems around the World, Council on Tall Buildings and Urban Habitat Journal (CTBUH Review), 2 (2008) pp. 18-29.

[3] Smith, P. F.: Architecture in a Climate of Change: A Guidance to Sustainable Design, Second Edition, Oxford Architectural Press, Britain, 2005.

[4] Gültekin, A., B. \& Yavaşbatmaz, S.: Sustainable Design of Tall Buildings, Journal of the Croatian Association of Civil Engineers Gradevinar, Croatia, pp.449-461, 2013

[5] Alparslan, B.: Design and Evaluation of an Example Building in Ankara in the context of Ecological Building Design Criteria (in Turkish), M.Sc. Thesis, Gazi University Institute of Science and Technology, 2010

[6] Sayın, S.: The Significance of the Use of Renewable Energy in our Country's Building Sector and the Opportunities of Utilizing of Solar Energy in Buildings (in Turkish), M.Sc. Thesis, Selçuk University Institute of Science and Technology, 2006.
[7] Enginöz, Y. K.: Green Home Certificate for Turkey (in Turkish). Bulletin of Yapı - Ecology in Construction, 365 (2012), pp. 30-31.

[8] Erten, D.: The Beta Version of National Certification System is Ready (in Turkish), Bulletin of Ekoyapı - Ecological Buildings and Settlements, Turkish Green Building Council, 9 (2012), pp.76-79.

[9] Turkish Standards Institution (TSE): TS 825 - Thermal Insulation Requirements for Buildings (in Turkish), Ankara, 2008.

[10] Republic of Turkey Prime Ministry, Turkey General Directorate of Legislation Development and Publication: Energy Efficiency Law (in Turkish), No. 5627, Ankara, 2007.

[11] Republic of Turkey Prime Ministry, Turkey General Directorate of Legislation Development and Publication: Regulation of Energy Performance of Buildings (in Turkish), No. 27075, Ankara, 2011.

[12] Hamamcı, C. \& Keleş, R.: Ecology (in Turkish), First Edition, Imge Bookstore, Istanbul, 2002.

[13] Bekar, D.: Examination of Active Energy Systems in Ecological Architecture (in Turkish), M.Sc. Thesis, Yıldız Technical University Institute of Science and Technology, Istanbul, 2007.

[14] Osso, A., Walsh,T. \& Gottfried, D.: Sustainable Building Technical Manual, Public Technology Inc., San Francisco, U.S.A., 1996. 
[15] Kayihan, K.S. \& Esin, T.: A Study Aimed to Determine Primary Ecological Building Criteria For Gebze and A Model Building Design (in Turkish), Journal of Environmental Protection and Ecology, 10 (2009) 3 pp. 664-677.

[16] Daniel, D.C.: The Solar House: Passive Heating and Cooling, Chelsea Green Publishing Company, Canada, 2002.

[17] Celebi,G. \& Aydin, A.B.: Evaluation of Building Materials in Sustainable Architecture Approach, (in Turkish), IV. National Ecology and Environment Congress, Izmir, pp.457-464, 2001

[18] Gültekin, A. B. \& Dikmen, C. B.: Analysis of Ecological Design Criteria in Architectural Design Process (in Turkish), VI. National Ecology and Environment Congress, Izmir, pp. 159-167, 2006.

[19] Gür, V.: A Design Support tool for Variable Building Skins in the scope of Sustainable Architecture (in Turkish), Ph.D Thesis, Istanbul Technical University Institute of Science and Technology, 2007.

[20] Çelebi, G. \& Gültekin, A. B.: Scope of Sustainable Architecture: A View from Conceptual Framework (in Turkish), Journal of Mimaran - Global Warming and Architecture, 1 (2007) 2, pp.3036.

[21] Gültekin, A. B. \& Alparslan, B.: Ecological Building Design Criteria: A Case Study in Ankara (in Turkish), Gazi University Journal of Science, 24 (2011) 3, pp. 605-616.

[22] Vickers, A.: Handbook of Water Use and Conservation: Homes, Landscapes, Industries, Businesses, Farms, Waterplow Press, Massachusetts, 2001.
[23] Davis, A.J.: Alternative Natural Energy Sources in Building Design, Simon \& Schuster, New York, 1981.

[24] Viorel, I., Boengiu, S. \& Viladut, A.: Eco-Ethics-Moral Values Involved in Ecological Education, Journal of Environmental Protection and Ecology 6 (2005) 2, pp. 476-481.

[25] Republic of Turkey, Ankara Governorship: Environment and Forest Directorate Ankara Province Environmental Status Report (in Turkish), Ankara, 2009.

[26] Özdemir, B. B.: Energy Efficient Building Design as Passive Systems for a Sustainable Environment (in Turkish), M.Sc. Thesis, Istanbul Technical University Institute of Science and Technology, 2005.

[27] Gazi University Central Campus, http://www.maps.google.com, 02.04.2013.

[28] Tasdemir, C. \& Ertokat, N.: An Evaluation on Physical and Mechanical Properties of Gas Concrete (in Turkish), $1^{\text {st }}$ National Building Material Congress, Istanbul, pp.425-437, 2002.

[29] Kislalioğlu, M. \& Berkes, B.: Ecology and Environmental Sciences (in Turkish), Remzi Bookstore, Istanbul, 2009.

[30] Topay, M.: Importance of Thermal Comfort in the Sustainable Landscape Planning, Journal of Environmental Protection and Ecology 13 (2012) 3, pp.1480-1487. 